

\title{
EGALITARIAN JUSTICE AND INNOCENT CHOICE
}

BY NIR EYAL

Journal OF ETHICs \& Social PHILOSOPHY

VOL. 2, NO. 1| JANUARY 2007 URL: WWW.JESP.ORG COPYRIGHT (C) NIR EYAL 2006 


\section{EGALITARIAN JUSTICE AND INNOCENT CHOICE Nir Eyal ${ }^{*}$}

HHIS ARTICLE ARGUES THAT, in its standard formulation, luck-egalitarianism is false. In particular, I show that disadvantages that result from perfectly free choice can constitute egalitarian injustice. I also propose a modified formulation of luck-egalitarianism that would withstand my criticism. One merit of the modification is that it helps us to reconcile widespread intuitions about distributive justice with equally widespread intuitions about punitive justice.

Before laying out my criticism, let me briefly describe luckegalitarianism and why some of its existing criticisms are off the mark.

\section{Standard Luck-Egalitarianism}

In the past, many egalitarians considered any inequality in people's lots to be unjust. By contrast, contemporary luck-egalitarians acknowledge the potential justice of inequalities that result from free choice. For example, luck-egalitarians would say that standard gambling losses do not diminish the justice of the resulting distribution and that such losses do not generate just claims for compensation. Luck-egalitarians contrast such disadvantages with disadvantages that do not result from the victims' choices or that result only from their un-free choices, such as genetic disease and structural unemployment. According to luck-egalitarians, the latter disadvantages are unjust.

For a few luck-egalitarians, these claims determine when the state should compensate for disadvantage. But for most luck-egalitarians, they determine only when the end-state distribution is in an important way unjust. Whether human-induced or "cosmic," such unjust distribution always gives the state a prima facie — but not always an actual — duty to compensate the disadvantaged. Luck-egalitarian injustice worsens things and often translates into an actual duty of the state to compensate victims whose fates are less than fully just. But few luck-egalitarians assume that such a duty is absolute and that it always exists. Compensating victims would sometimes be prohibitively expensive, unjust toward other people, self-defeating, contrary to deontological constraints or beyond the state's responsibility.

\footnotetext{
* I wish to thank Alon Harel for conversations that inspired this article. Initially we planned to be coauthors, but eventually I wound up writing this article. For other especially helpful ideas, I wish to thank Richard Arneson, Leah Belsky, Francesco Biondo, John Broome, Simon Clarke, Jerry Cohen, David Enoch, Leslie Francis, Lindsay Hampson, Adaeze Igboemeka, Daniel Jacobson, Ron Mallon, Michael Otsuka (who discussed the evolving ideas with Harel), Kasper Lippert-Rasmussen, Thomas Pogge, Tony Rønnow-Rasmussen, Alex Rajczi, Henry Richardson, Shlomi Segall, David Shalowitz, Saul Smilansky, David Sobel, Daniel Statman, Larry Temkin, Steve Wall and Daniel Weinstock. I am also grateful to audiences at the Fourth European Congress of Analytic Philosophy and at the Philosophy departments of Glendon College, Université de Montréal, Sheffield University, Hebrew University and the University of Utah.
} 
For example, it might turn out that the only way for the state to compensate for a disadvantage was by practices that would be humiliating to the recipients. If the need to avoid such humiliation were stronger than the need for compensation, most luck-egalitarians would object to the state's compensating recipients for the disadvantage. Luck-egalitarian injustice is but one important component of the complex web of considerations that together determine what would constitute correct conduct for the state.

Contemporary criticisms of luck-egalitarianism sometimes overlook this complexity. Critics point out that compensation can be a bad policy, as if luck-egalitarians deny that it ever is. In the critics' caricature, luckegalitarianism effectively assigns the state an absurd, categorical duty to compensate citizens for all disadvantages for which these citizens are not responsible. A great many considerations bear on normative compensation policy. No short formula purporting to define when compensation is a duty all things considered may succeed - whether that formula resembles luck-egalitarianism, democratic equality or still other theories.

I shall call the complex view that encapsulates these luck-egalitarian ideas standard luck-egalitarianism:

That someone incurs a disadvantage without having chosen freely to risk incurring it is, in a central respect, unjust. If, however, that disadvantage results from that person's own free choice to take that risk, then (barring prioritarian considerations) that disadvantage can remain perfectly just.

Jerry Cohen, John Roemer, Richard Arneson, Larry Temkin and many other luck-egalitarians are committed to standard luck-egalitarianism or to something very much like it. Many anchor it in the ideal of equality of opportunity. They disagree about many other issues: What constitutes a disadvantage - only absolute harms, or also relative ones; the frustration of preferences, or only "objective" harms? Do disadvantages that conform to "victims" tastes always rest on free choices? In the distribution of disadvantages that do not arise from victims' free choices, does justice require equality or priority? Who should distribute relief of bad brute luck? In spite of these differences, standard luck-egalitarianism is common to all luck-egalitarian theories. ${ }^{1}$

${ }^{1}$ Luck-egalitarians always accept something like standard luck-egalitarianism. See Gerald A. Cohen, "On the Currency of Egalitarian Justice," Ethics 99 (1989): 906-44; "Expensive Taste Rides Again," in Justin Burley (ed.), Dworkin and his Critics (Oxford: Blackwell, 2004): 3-29; "Luck and Equality: A Reply to Hurley" (forthcoming, Philosophy and Phenomenological Research); Richard Arneson, "Equality and Equality of Opportunity for Welfare," Philosophical Studies 56 (1989): 77-93. Reprinted in Louis Pojman and Robert Westmoreland, Equality: selected readings (New York: Oxford UP, 1997): 228-41; "Luck Egalitarianism and Prioritarianism," Ethics 110 (2000): 339-49; "Luck and Equality II," Aristotelian Society Supp 75 (2001): 73-90; "Why Justice Requires Transfers," Social Philosophy \& Policy 19 (2002): 172-200, pp. 198-9; John E. Roemer, "A Pragmatic Theory of Responsibility for the Egalitarian Planner,” Philosopby \& Public Affairs 22 (1993): 146-66; Theories of Distributive Justice (Cambridge, Mass.: Harvard UP, 1996), Chs. 7, 8; Larry Temkin, Inequality (New York: Oxford University Press, 1993); "Egalitarianism Defended," Ethics 113 (2003): 764-82; several contributions in Theoria 69 (2003); Kasper Lippert-Rasmussen, "Egalitarianism, Option Luck, and Responsibility," Ethics 111 (2001), pp. 548-79; "Hurley on Egalitarianism and the Luck-Neutralizing Aim," Politics, 
In this article I criticize standard luck-egalitarianism. I hold that disadvantages that you freely choose to risk incurring can remain unjust in egalitarian terms. To show this, I advance two counterexamples to standard luck-egalitarianism. Both involve permissible free choice to riskincurring disadvantage. I suggest that such free choice does not vindicate the resulting disadvantages, which remain unjust.

I then propose an alternative formulation of luck-egalitarianism, which I call modified luck-egalitarianism. The modified formulation captures the deep and genuine insight of luck-egalitarians. It also deals with the two counterexamples better than standard luck-egalitarianism does. I then address possible objections to my argument for modified luckegalitarianism. Finally, I suggest that modified luck-egalitarianism could contribute to a theory of justice itself: a theory of what is common to both distributive justice and punitive justice and makes both into manifestations of justice. Justice in all its instantiations is the enemy of innocent disadvantage. A long-standing puzzle of moral luck in punitive contexts may thereby dissolve.

\section{Two Counterexamples}

The unjust fates of Hero and Acceptable cast doubt on standard luckegalitarianism.

a) Hero

When a fire breaks out in the neighborhood, Hero freely chooses to risk his own house by deciding to put out the fire that will soon consume a neighbor's house, from which he hears a baby crying. If he were first to deal with the fire at his own empty house, he would not have saved the baby. Compare Hero to Inconsiderate, another neighbor who hears the crying baby, but who rushes first to his own empty house to try to prevent it from burning down. Eventually, the houses of both Hero and Inconsiderate suffer similar damage. Had Hero not saved the neighbor's baby, he would have saved his own house. No company would insure his house against fires, a fire-proof house was prohibitively expensive, and

Philosophy \& Economics 4(2): 249-65; Erik Rakowski, Equal Justice (New York: Oxford UP, 1991); Peter Vallentyne, "Brute Luck, Option Luck, and Equality of Initial Opportunities," Ethics 112 (2002): 529-57; Philippe Van Parijs, Real Freedom for All (Oxford: Clarendon Press, 1995), pp. 50-1, 80-2, 92-6; Will Kymlicka, Contemporary Political Philosophy (Oxford: Oxford UP, 1990), pp. 71-85; Amartya K. Sen, Inequality Reexamined (Cambridge: Cambridge UP, 1992), pp. 148-50; Hillel Steiner, "How Equality Matters," Social Philosophy \& Policy 19 (2002): 342-56, pp. 348-49; Thomas Nagel, Equality and Partiality (New York: Oxford UP, 1991), pp. 71-2 (Nagel acknowledges additional principles of justice.) Some authors see luck-egalitarianism as an extension of Rawls's thoughts on eliminating natural inequalities; others deny that Rawls was a luckegalitarian. Ronald Dworkin's seminal "What is Equality? Part 2: Equality of Resources," Philosophy \& Public Affairs 10 (1981): 283-345, reprinted in his Sovereign virtue (Cambridge, Mass.: Harvard UP, 2000), pp. 65-119, initiated luck-egalitarian theory. However, Dworkin recently renounced luck-egalitarianism. See his "Equality, Luck and Hierarchy," Philosophy \& Public Affairs 31 (3): 190-98, p. 192. 
there was no way to prevent the fire in advance. In all other relevant respects, Hero and Inconsiderate are equal.

The government's compensation policy is such that the damage to Hero's home goes uncompensated, whereas Inconsiderate enjoys full compensation. Imagine, for instance, that the policy holds citizens accountable for putting out fire to their own homes in order to contain moral hazard, or that the policy is a legal fluke. From an egalitarian point of view, is the resulting distribution entirely just: no house for Hero and a newly restored house for Inconsiderate?

Surely Hero's fate is less than entirely just. Even if compensation exclusively for Inconsiderate, is, all things considered, sensible (say, as a necessary incentive to guard one's own home), that policy is sensible even though a certain injustice accrues to Hero. Note, however, that standard luck-egalitarianism would detect no egalitarian injustice in Hero's fate. To use Dworkin's familiar terms, standard luck-egalitarianism would construe Hero's bad luck (fire damage to his home) as bad "option luck." Hero's choice to risk his house was free. Inconsiderate's bad luck, on the other hand, is bad "brute luck." Inconsiderate's only relevant choice was to mitigate risk to his home as much as he could.

Despite standard luck-egalitarianism, the outcome - damage to Hero alone, both in absolute and in relative terms - seems less than entirely just. Hero's choices and conduct are incapable of excusing the otherwise unjust inequality. Furthermore, the injustice seems to be precisely what luck-egalitarians attempt to reference through the inappropriate language of lack of free choice. The injustice clearly does not reflect historic entitlements, promise-breaking, or lack of due mercy for wrongdoers. Nor does the injustice reflect considerations of desert: see section 4, \a below. Hero suffers from egalitarian injustice.

In a recent discussion of a similar example, luck-egalitarian Larry Temkin similarly concludes that noncompensated damage that you suffer through a morally mandated attempt to save a baby cannot be just, from an egalitarian point of view. ${ }^{2}$ Contrary to the standard formulation of luck-egalitarianism, it therefore seems that luck-egalitarian injustice can persist despite a victim's fully free choice to risk incurring the relevant disadvantage.

Risk-taking that is morally neutral supplies additional evidence that free choice does not always diminish egalitarian injustice.

b) Acceptable

Acceptable is a U.S. citizen who freely accepts a risk to her home by living in a U.S. county where earthquakes occur, albeit rarely: once in a thousand years. As she also realizes, in other, virtually quake-free counties, earthquakes are even rarer: they occur only once in a million years. Acceptable could have moved to one of those virtually quake-free counties, except that she would have incurred substantial, albeit endurable,

2 Larry Temkin, "Exploring the Roots of Egalitarian Concerns," Theoria 69 (2003): 125-51, p. 144. However, Temkin's modification differs from mine. See section 4, \$d below. 
personal cost in terms of the hassle of moving and the loss of a home to which she is slightly attached. Moving would not be so bad as to effectively force Acceptable to stay. But moving would be a real drag, and it seems pointless for Acceptable to do so, given the absence of specific quake warnings and given how rarely earthquakes take place, even in her home county. No insurance policy against property damage from earthquake is available, and a quake-proof home is prohibitively expensive. With the exception of one citizen, named Saintly, nobody else moves to another, virtually quake-free, county for the sole reason of avoiding earthquake damage.

Some time later, a sudden earthquake destroys both Acceptable's home and Saintly's home. The federal government fully compensates Saintly. It can afford to compensate Acceptable and fellow residents of her county and, due to legal complications, it is the only party that may compensate them. Would it be just, from an egalitarian point of view, for Acceptable and her fellow residents to incur the resulting damage without being compensated? To me, this is counterintuitive. Elizabeth Anderson, Kasper Lippert-Rasmussen, Martin Sandbu, Peter Vallentyne, Amartya Sen, Michael Otsuka, John Oberdiek and Eric Rakowski, who discuss similar examples, seem to share that intuition. ${ }^{3}$ Full egalitarian justice is incompatible with Acceptable's suffering that bad lot with no compensation when others are fully compensated. If such remote risks were valid grounds for luck-egalitarians to deny compensation, then grounds for denial could almost always be found. For almost any risk can be mitigated if one takes some extraordinary measure. Hero, for example, could have built his house from costly fireproof metals, or spent his days inside to extinguish potential flames. Luck-egalitarianism would lose all political edge.

Thus, standard luck-egalitarianism saddles luck-egalitarians with an absurd view that few luck-egalitarian writers would endorse: anyone freely choosing to take a risk, even someone like Acceptable, supposedly waives all just claims for egalitarian compensation. Luck-egalitarians should move beyond phrasing their ethical principle along the lines of standard luck-egalitarianism. They should seek a formulation that better accommodates their own and other philosophers' intuitions.

Someone might respond that that absurd and politically antiegalitarian implication of standard luck-egalitarianism indicates only that what I call "standard luck-egalitarianism" is an uncharitable interpretation of what luck-egalitarians say. ${ }^{4}$ But certainly luck-egalitarians often write as

${ }^{3}$ Elizabeth S. Anderson, "What Is the Point of Equality?" Ethics 109 (1999): 287-337, p. 296; Sandbu, "On Dworkin's brute-luck-option-luck distinction and the consistency of brute-luck egalitarianism," Politics, Philosophy \& Economics 3(3): 283-312, pp. 294-9; Lippert-Rasmussen, pp. 557-58; Michael Otsuka, "Luck, Insurance and Equality," Ethics 113 (2002): 40-54, p. 45; Vallentyne, p. 533; Sen, p. 149; John Oberdiek, "Choice, Value, and the Perfection of Distributive Justice," unpublished manuscript; Rakowski, p. 7980. All these writers discuss cases in which it is very expensive to mitigate risk more than one does.

${ }^{4}$ As Jerry Cohen did, in several emails to the author. However, Cohen seems to accept my Hero example as a genuine counterexample to existing luck-egalitarian formulations. 
if their sole focus were whether the choices of disadvantaged parties were "free" - that is, truly "avoidable," such that "opportunity" is protected. That the standard version of the principle is unappealing and strays from the broader goals that luck-egalitarian writers seek to promote does not show that these writers do not write in favor of that standard version. Even if luck-egalitarians tacitly endorse a principle that differs from the claim that they espouse, that tacit principle should be made explicit.

In my view, the injustices to Hero and to Acceptable each call standard luck-egalitarianism into question. Readers who agree with me at least on one of these examples may wish to explore the modified formulation of luck-egalitarianism that I suggest below, either as an alternative to existing luck-egalitarian theories or as the expression of a somewhat latent idea toward their aim.

\section{Modified Luck-Egalitarianism}

I propose replacing standard luck-egalitarianism with modified luckegalitarianism:

That someone incurs a disadvantage without having chosen culpably to risk incurring it is, in a central respect, unjust. If, however, that disadvantage results from that person's own culpable choice to take that risk, then (barring prioritarian considerations) that disadvantage can remain perfectly just. "Culpable" choice is understood as a free and at least somewhat morally wrong choice.

The only difference between standard luck-egalitarianism and modified luck-egalitarianism is that the latter focuses on the moral culpability of choice, instead of its sheer freedom. This allows luck-egalitarianism to judge as unjust disadvantages that result from free but morally praiseworthy or neutral choice. I believe myself to be explicating the common understanding of culpability, which assumes both freedom and a degree of wrongdoing. The culpability of a choice increases in accordance with the

Cohen additionally claimed that Dworkin worded his original definition of bad option luck as though he were attempting to exclude cases such as Acceptable's. Let us examine that claim. Dworkin's definition reads: “Option luck is a matter of how deliberate and calculated gambles turn out — whether someone gains or loses through accepting an isolated risk he or she should have anticipated and might have declined. Brute luck is a matter of how risks fall out that are not in that sense deliberate gambles." (Dworkin, "What is Equality? Part 2," p. 293). I italicized the words that might substantiate Cohen's claim that Dworkin was hedging against Acceptable-style cases. But these words more probably rule out penalizing people for impulsive, misinformed or incorrectly calculated decisions - decisions that are neither "deliberate" nor "calculating" and that these people "should" prudentially not have made. This interpretation also chimes in with Dworkin's later clarification that "what equality requires is not that people be made indifferent between... their... resources and the... resources of any other person... but rather that people be put in the position they would probably occupy if they had had a chance to insure against illness or lack of talent on equal terms." "Sovereign Virtue Revisited," Ethics 113 (2002): 106-43, p. 123.) One assumes that Dworkin refers to the position people would occupy had they made a calculated and deliberate decision on that occasion. I italicized words in his definition of option luck that presumably convey that. 
freedom of that choice, but only if that choice is at least somewhat morally wrong. A choice cannot be culpable, at least in my sense, if it is innocent forced or permissible. Fully permissible choice, no matter how free, is not culpable. ${ }^{5}$

Thus, on modified luck-egalitarianism, egalitarian justice opposes innocent disadvantage — disadvantage relative to others that one either could not avoid or that one could avoid but made a fully permissible choice not to avoid. In other words, unequal (or non prioritarian) innocent suffering detracts from egalitarian justice. ${ }^{6}$

Why divert luck-egalitarian theory away from a focus on opportunity, capability or access to advantage to a focus on the "moralized" notion of innocent disadvantage, which mitigates the difference between luck egalitarianism and classical outcome egalitarianism? In the final section of the article I suggest that this modification ministers to widespread convictions about just punishment. For now, let me argue only that this modification permits luck-egalitarianism to cope with the potential counterexamples of Hero and of Acceptable (and with similar potential counterexamples proposed by Temkin, Anderson, Lippert-Rasmussen, Sandbu, Vallentyne, Sen, Otsuka and Rakowski).

Hero's choice to save the baby is free. But his praiseworthy choice cannot be said to be culpable. Hence, it is unjust that Hero incurs uncompensated disadvantage through that choice.

Acceptable's choice not to move to an earthquake-proof county does not make her a heroine. Her choice is not praiseworthy. And yet, her choice is permissible. Morality does not expect people to change their counties of residence simply in order to avoid a remote risk of an earthquake; certainly a well-ordered society does not expect citizens to change counties in such situations. Acceptable's conduct is arguably very different from that of a person who exploitatively surfs waves without working and relies on others' guarantee of basic income; who inconsiderately nurtures an expensive taste for which she asks society to cater; who impertinently tears up her welfare money, then demands more because her money is gone; or who recklessly refuses to insure her house against earthquake damage or to move when low-cost insurance is available and an impending earthquake is predictable for known geological reasons. It is the arguable innocence of Acceptable's choice that makes her disadvantage, or refusal to compensate her for it, unjust. (This statement is not circular: see section 4 , §f below.)

${ }^{5}$ I leave open the question whether the relevant notion of moral wrongness is objective or subjective: whether, for example, a failed assassination attempt is "morally wrong." I also leave open the question whether personal vice that does not wrong others is "morally wrong."

${ }^{6}$ While innocent suffering is always bad (other things equal) and while we typically have reason to diminish innocent suffering, innocent suffering is unjust in egalitarian terms only when that suffering exceeds the suffering of some others (or when that suffering violates prioritarian constraints). To illustrate, suppose that all human beings innocently suffer in a certain way. Suppose, for example, that none culpably chooses to risk being mortal, and yet, that all are mortal. This state of affairs, I hold, is not unjust in egalitarian terms, although it can be bad in other ways. 


\section{Addressing Objections to Modified Luck-Egalitarianism}

I consider seven possible objections to my modification of standard luckegalitarianism: objections in relation to desert, moral incentives, reasonable avoidability, the supererogatory, philanthropy and gambling, state neutrality and circularity.

a) Desert

The cases of Hero and Acceptable might be thought to indicate merely the need to replace or to couple standard luck-egalitarianism with a principle of desert rather than modifying standard luck-egalitarianism. Hero, for example, is clearly more deserving of reward than Inconsiderate, and may on that basis be said to deserve compensation; and Acceptable is not really deserving of punishment, and may therefore be said not to deserve earthquake damage with no compensation. Hence, some principle of desert could allegedly explain our judgments regarding Hero and Acceptable and render my modification of luck-egalitarianism superfluous.

However, desert-based rewards and punishments do not eliminate the need to compensate for damage in terms of modified luckegalitarianism. While a principle of desert is a welcome addition to modified luck-egalitarian compensation (see section 5 below), justice requires modified luck-egalitarian compensation as well.

Imagine a society in which a principle of desert is being strictly followed. The results of all gambles are effectively obliterated. Optional gamblers are granted precisely what they deserve. Gamblers' lots are of course tied to the fact that they gamble, which affects their deserts. However, their lots are not tied to the arbitrary outcomes of their gambles, namely, to their option luck. Plainly, such a society differs from a (standard or modified) luck-egalitarian one. Strict adherence to a desert principle obliterates all luck, regardless of whether it is brute luck or option luck, luck following innocent choice or culpable choice. But at the heart of luck-egalitarianism is the profound observation that when we make a choice of a certain kind (say, a free or a culpable choice) to take a risk, then we waive our claim for an equal level of advantage regardless of how things pan out later. Egalitarian justice tolerates either non-compensated disadvantage or (fully or partly) compensated disadvantage. Overlooking that observation indicates the failure of a principle of desert, a failure that luck-egalitarians, in particular, find problematic. Surely that profound insight must remain one of our trails in honing luck-egalitarianism. (The dependence of egalitarian justice on the arbitrary results of many gambles may have not been noticed by Shelly Kagan, who suggests that sound egalitarian concerns are wholly reducible to concerns of desert.')

What about rewarding and punishing people in proportion to their personal desert in combination with compensating them in standard luckegalitarian terms? Perhaps that combination would render modified luck-

7 See his "Equality and desert," in Louis P. Pojman \& Owen McLeod (eds.), What do we deserve? (Oxford: Oxford UP, 1999), pp. 298-314. 
egalitarianism superfluous? Unfortunately, that combination is not entirely just either. For example, it permits a person who risks having his own house burnt in order to save a neighbor's baby to receive a prize for his praiseworthy act. But that prize need not be nearly as substantial as the loss of his home. A person's praiseworthy decision to focus on the neighbor's baby need not be praiseworthy enough to call for a substantialenough award: one may save the baby when the risk to one's own house is still low. In this instance, the decision will be only somewhat praiseworthy, justifying only a small desert-based prize. Occasionally, however, such a decision will lead to the ruin of one's own home.

Thus, desert-based rewards and punishments do not eliminate the need for compensation in accordance with modified luck-egalitarianism. Unaccompanied by a luck-egalitarian compensation, or accompanied only by standard luck-egalitarian compensation, desert-based rewards and punishments would not necessarily prevent the injustices to Hero and Acceptable. While for independent reasons I believe that a full theory of justice incorporates a desert element as well, that element does not fully replace the modified luck-egalitarian element. With or without a principle of desert, modified luck-egalitarianism looks indispensable.

\section{b) Moral Incentives}

Egalitarian justice probably requires, among other things, prospects for future (egalitarian) justice, and perhaps for future good in general. Such prospects require incentives for creating further prospects. Rewarding Hero could motivate him and everyone else to follow his heroic example. Compensation and perhaps a prize for Hero are therefore moral incentives for furthering egalitarian justice. That supposedly explains why denying compensation to Hero would contradict egalitarian justice, thereby supposedly rendering my modification of luck-egalitarianism superfluous.

But construing the requirement for compensation as a moral incentive does not explain why Acceptable should receive compensation. She chooses not to behave in the best possible way: unlike Saintly, Acceptable does not move to a virtually quake-free county. The most efficient moral incentive might be not to compensate her at all. Noncompensation could spur others into better choices. An opponent may respond that an efficient moral incentives scheme may reserve noncompensation only against choices that are worse than Acceptable's - actual crimes, say. But it is by no means clear that an efficient incentives scheme includes compensating Acceptable. Thus, the value of moral incentives does not account for her clear prima facie claim for compensation. Modified luck-egalitarianism provides a far more straightforward account. ${ }^{8}$

${ }^{8}$ Even with respect to Hero, an explanation in terms of moral incentives seems to miss the point. Failing to compensate Hero would be unjust toward Hero, and not (only) toward potential victims of the deranged incentive structure, who are the foci of an explanation in terms of moral incentives. Moreover, consider Major Hero and Minor Hero. Major Hero saves the neighbor's baby believing that he will not be compensated if his own house catches fire, while Minor Hero saves his neighbor's baby believing that he, Minor Hero, will be compensated. As Alon Harel pointed out to me, incentive consid- 


\section{c) Reasonable Avoidability}

Peter Vallentyne considers whether luck-egalitarians should support compensation for bad outcomes that the agent can avoid, provided that these outcomes are not "reasonably avoidable." An outcome is reasonably avoidable when "there is, for the agent, some reasonable choice that avoids that outcome." Vallentyne explains what makes a choice reasonable: "One view is that it is in the agent's best interest. Another view is that it is adequately (either in absolute terms or relative to the best choice) in the agent's interests."

It is tempting to assume that Vallentyne's reasonable-avoidability condition explains why Acceptable ought to receive luck-egalitarian compensation. Moving to a different county merely to avoid a remote risk of an earthquake would not be a reasonable choice for Acceptable; moving would not be in Acceptable's best interest, especially relative to not moving. Hence, the difficult cases I describe might be thought to show only that Vallentyne's reasonable-avoidability condition should be included in luck-egalitarian theory, not that the theory needs to be "moralized" in the way I propose.

But including Vallentyne's reasonable-avoidability condition in luckegalitarianism has absurd implications. Vallentyne himself does not clearly endorse what I call "Vallentyne's reasonable-avoidability condition." For one thing, when great success is far more likely than loss, he plausibly sees gambling as "in the agent's best interest," and therefore "adequately (either in absolute terms or relative to the best choice) in the agent's interests." On Vallentyne's criteria, it is not reasonable not to gamble in such a case and gambling is not reasonably avoidable. However, on Vallentyne's reasonable-avoidability condition, such gambling would mandate that the gambler be compensated for her loss under luckegalitarianism. When great success is far likelier than loss, gamblers lack reasonably avoidable alternatives to gambling. This is an absurd view of luck-egalitarianism, of course. Failed opportunistic gambles are paradigms of bad option luck and often of culpable choice (see section 4, Se below) for which luck-egalitarianism does not demand compensation. We should not correct standard luck-egalitarianism by plugging Vallentyne's reasonable avoidability condition into it. Reshaping standard luck-egalitarianism into modified luck-egalitarianism is a better idea.

Plugging Vallentyne's reasonable avoidability condition into standard luck-egalitarianism can also generate absurdities in the context of Acceptable's choice: her failure to move to a different county despite the risk of earthquake where she is. That version of standard luck-egalitarianism

erations oddly demand giving Minor Hero higher compensation than Major Hero should receive: Major Hero would have saved the baby anyhow and evidently does not require external incentives for him to do so. As Harel notes, that result is unjust. Clearly, justice does not require greater compensation for Minor Hero than it does for Major Hero.

${ }^{9}$ Vallentyne, p. 533. Lippert-Rasmussen's “reasonable, guaranteed minimum requirement" (Lippert-Rasmussen, p. 558); Michael Otsuka's "reasonably priced" insurance against damage (Otsuka, pp. 45f.); and Martin Sandbu's "entitlements" express similar ideas. In an email communication, Jerry Cohen embraced Vallentyne's "reasonably" qualifier. 
would be absurd unless her failure is morally permissible, that is, unless modified luck-egalitarianism kicks in. Imagine that moving to a different county remained every bit as uncomfortable as it is now, both in absolute terms and relative to not moving. That would prevent moving to a different county from becoming "reasonably avoidable" on Vallentyne's criteria. But imagine also that rebuilding houses that had been struck by an earthquake, or that compensating residents for earthquake damage, were astoundingly costly for society, or that the risk of an earthquake were very high. These conditions would arguably make it morally wrong not to move elsewhere. That the agent move to another county would become very urgent for society, and remain a mere drag - not an unbearable personal sacrifice - for the agent. Morality would presumably require the agent to move. You can feed additional assumptions that would morally require that the agent move. That moral requirement need not itself rest on luck-egalitarianism, so the assumptions do not beg questions about what luck-egalitarianism requires.

In such conditions, does it remain unjust if there is no compensation for people who refuse to move elsewhere, that is, who refuse to avoid impending earthquake damage despite the astounding cost to society? Intuitively, it does not. Society might compensate such people out of compassion, but not because it would be unjust for them to go uncompensated. Arguably, the reason that not being compensated is just is that, in these circumstances, it would be selfish, callous and therefore culpable for these adamant people not to leave that earthquake-prone county. Justice requires compensation only for innocent disadvantage.

It is especially clear that Vallentyne's reasonable avoidability condition cannot account for the injustice of Hero's fate. Hero would be much better off saving his own house. In Vallentyne's sense, he could reasonably avoid saving the baby. But building Vallentyne's reasonable avoidability condition into standard luck-egalitarianism does not cope successfully with the counterexamples of Acceptable and Hero. Using modified luckegalitarianism does. ${ }^{10}$

\section{d) The Supererogatory}

Some probably agree that praiseworthy choice preserves luck-egalitarian claims for compensation, but only when that praiseworthy choice conforms to duty. Unlike modified luck-egalitarianism, they deny that the victim maintains her claim for compensation if her praiseworthy choice was a purely supererogatory action, and not simply fulfilling her duty.

This theoretical analysis has an initial appeal, but it is incompatible with our intuitions about concrete cases. Compare Super Hero with Ordinary Hero - two persons who made choices similar to Hero's in situations almost identical to his. By saving the neighbor's baby instead of his own house, Super Hero acted in a supererogatory way. Super Hero's house, which seemed very likely to burn unless he immediately intervened, contained all of Super Hero's savings and the only copy of a novel

${ }^{10}$ Vallentyne's reasonable avoidability condition is fraught with further problems that he himself brilliantly points out. See Vallentyne, p. 534. 
on which he has been working for 21 years. The neighbor's house, on the other hand, seemed unlikely to burn so badly that the baby would be jeopardized before the firemen could arrive. Moreover, putting out the fire required Super Hero to pass through a burning passageway and risk severe burns. Thus, to stamp out a remote danger to the neighbor's baby, Super Hero imperiled his own property, projects and health. It seems fair to conclude that he acted beyond the call of duty. Compare Super Hero to Ordinary Hero, who also acted morally by saving the neighbor's baby when fire broke out in his neighborhood. But Ordinary Hero had nothing of special value in his house, and the fire there seemed to subside anyhow, while the flames next door seemed as though they might consume the baby unless Ordinary Hero intervened immediately (an action that would not involve physical risk to himself). Arguably, saving the neighbor's baby was Ordinary Hero's moral duty. He would be morally blameworthy had he not attempted it. It so happens that both Super Hero's and Ordinary Hero's houses burned down in their respective neighborhoods. On the relevant analysis, Super Hero would lack a just claim for compensation, whereas Ordinary Hero would have a claim: only Super Hero's acts are supererogatory. But that seems counterintuitive. ${ }^{11}$ Despite the analysis, Super Hero's claim for compensation seems at least equal to, and probably greater or clearer than, Ordinary Hero's.

Another reason to prefer modified luck-egalitarianism to this analysis is that that analysis does not account for Acceptable's egalitarian claim for compensation. By not moving to a different county to avoid earthquake, Acceptable did not fulfill her moral duty, but, at most, she did not violate her duty. Hence, the position that free acts that fulfill duties preserve egalitarian just claims for compensation does not explain Acceptable's egalitarian claim for compensation. Again, modified luck-egalitarianism provides the most comprehensive and accurate account of our intuitions about concrete cases.

\section{e) Philanthropy and Gambling}

Most people do not find it problematic that philanthropists are not fully compensated — by the state, say — for the pecuniary losses involved in philanthropy. Philanthropists choose to give their money away, and it seems absurd to compensate them for these particular choices. ${ }^{12}$ Similarly, most people, and luck-egalitarians in particular, see gambling losses as paradigms of bad option luck, for which justice does not require that the gambler be compensated. Standard luck-egalitarianism easily explains this, since losing money through philanthropy and through unsuccessful gam-

${ }^{11}$ See also Temkin, "Exploring the Roots," pp. 144-45; Arneson, "Luck and Equality," p. 85.

${ }^{12}$ Michael Otsuka made this objection in a conversation with Alon Harel, and John Broome and Larry Temkin made it to me. See also Temkin's comments on parents who strive to give their children better lives than they themselves had ("Egalitarianism Defended," p. 767), and on supererogatory acts (section 4, \$d above). Cohen expressly allows free self-sacrifice to justify inequality, including it among the kinds of choice freely made to risk or incur disadvantage ("On the currency of egalitarian justice," p. 916). 
bles generally results from a free choice to take a risk (in the case of philanthropy, a 100 percent risk). According to standard luck-egalitarianism, free choice to take a risk justifies resulting disadvantage. By contrast, modified luck-egalitarianism might seem to recommend compensation for most philanthropists and unsuccessful gamblers as a matter of egalitarian justice: philanthropy and gambling are usually seen as innocent practices - the former is typically praiseworthy. Free choices by philanthropists and gamblers to forgo or to risk their own money are usually seen as innocent. Modified luck-egalitarianism would therefore appear to entitle most philanthropists and unsuccessful gamblers to just egalitarian compensation - although compensation is not required.

My main response to this objection rests in the quantity and the variety of alternative reasons why generally we should not fully compensate philanthropists and unsuccessful gamblers. The absence of luckegalitarian injustice is rarely among those reasons.

But first, consider the rare occasions in which philanthropists and truly innocent (see below) gamblers receive "compensation" by natural means. Nature Herself blesses them with compensatory advantages. Intuitively, we agree that such "compensation" promotes egalitarian justice. For example, someone chooses freely to donate a lung to a stranger despite the expected repercussions to the donor's health. The highly generous donor then discovers, to her surprise, that her body functions every bit as well as it did prior to the donation. That surely is a particularly fortunate event. The reason is not only that no one is disadvantaged but also that her valiant choice does not disadvantage the generous donor. A simple explanation of the intuition that such natural "compensation" promotes egalitarian justice is that disadvantage incurred through valiant choice is unjust. ${ }^{13}$ Similarly, imagine a gambler who has a 95 percent chance of winning $\$ 1,000,000$ and only a 5 percent chance of losing $\$ 100$. If she wins, she will donate the prize money to charity or distribute it equally among all citizens — she has already precommitted. Hence, success at gambling would not involve relative disadvantage for anyone; it would not undermine egalitarian justice and it is truly innocent (most gambles are different, and they are somewhat culpable: see below). Alas, she loses. She is now $\$ 100$ poorer than fellow citizens. On the way home, however, she finds a $\$ 100$ note on the street. This surely is a fortunate event, in part because fully innocent choice to take a risk does not cancel the unfairness of resulting disadvantage. ${ }^{14}$

${ }^{13}$ Therefore I believe that Cohen is too quick in mapping self-sacrifice, alongside unsuccessful gambles and other culpable acts as "acts that justify inequality" ("On the currency of egalitarian justice,” p. 916.) Self-sacrifice can give rise to unjust disadvantage when it is truly heroic, and not merely unhelpful or carried to a fault — in other words, when self-sacrifice is truly innocent.

${ }^{14}$ Because the gambler faced only a small chance of losing, her level of heroism and moral desert is not so high. Therefore, even if justice includes a desert component (as I believe it does: see section 5 below), there is no guarantee that the gambler's level of personal desert is high enough to entitle her to the full $\$ 100$ that she lost, simply on desert grounds. Personal desert could potentially entitle her only to $\$ 10$, say, or $\$ 20$. (We may also imagine that the gambler's chance of losing $\$ 100$ is much smaller than 5 percent, so 
Why then is it typically acceptable that we do not fully reimburse philanthropists and unsuccessful gamblers? One reason is that philanthropy and gambling involve express consent to incur or to risk pecuniary loss. Unlike Hero and Acceptable, philanthropists and gamblers waive their claims to the money lost — one, by signing a check to a charity, the other, by signing an agreement with a casino house. An express waiver of a right can end one's claim to use that right quite apart from luckegalitarian considerations. Such waivers can independently explain why philanthropists and gamblers lack a just claim for compensation.

One other reason is that the reimbursement of philanthropy and gambling losses might promote the general belief that such losses will be reimbursed. This would undermine the very institutions of philanthropy and gambling. These institutions are defined as involving the potential loss of money without compensation. Undermining these institutions would have deprived us of their intrinsic goods - manifest social solidarity in the case of philanthropy and thrills in the case of gambling. This gives us independent reason not to reimburse philanthropy and gambling losses.

A third reason against the compensation of philanthropy and gambling losses is that such compensation is liable to degenerate into a public-money "pump": people could donate all their money to their favorite charities, or gamble all of it, knowing that they will be fully reimbursed for any money lost. It is important to thwart public-money "pumps."

These reasons for not reimbursing philanthropists and gamblers account, I propose, for our intuitive objection to doing so. These reasons make such compensation bad policy, all things considered, despite the genuine (modified luck-egalitarian) injustice that accrues to innocent philanthropists and innocent unsuccessful gamblers when they are not being fully reimbursed. Such reimbursement would typically promote (modified) egalitarian justice, a desirable outcome, other things equal. But the value of promoting egalitarian justice is defeated by strong independent reasons against such reimbursement. I have already argued that luckegalitarianism concerns a mere prima facie duty.

With respect to gambling, a further consideration applies. From the point of view of modified luck-egalitarianism, gambling is typically culpable - somewhat wrong - and not morally neutral. In standard cases, gambling aims at amassing profit without sharing it with non-gamblers. That would impose relative disadvantage on them, and one that does not stem from their own culpable choice: unlike refusal to work, refusal to place self-interested bets seems morally innocent. Thus, gambling aims at bringing about a distribution of goods that is unjust, from a modified luck-egalitarian point of view: within that distribution, some incur innocent relative disadvantage. Since aiming at a condition that involves injustice is typically culpable, gambling is typically culpable. Therefore, most unsuccessful gamblers lack a modified luck-egalitarian claim for compen-

she deserves even less.) The best candidate explanation for her intuitive entitlement to the full $\$ 100$ compensation remains modified luck-egalitarianism. 
sation. Our intuition that gambling losses should not be compensated meshes well with modified luck-egalitarianism.

\section{f) State Neutrality}

The moralized nature of modified luck-egalitarianism might generate the worry that a state that respects modified luck-egalitarianism will act on a determinate conception of the good: state officials would decide what to compensate based on moralistic judgments regarding moral culpability, and that would seem to violate state neutrality. ${ }^{15}$

But modified luck-egalitarianism (like standard luck-egalitarianism) is not directly about what the state should do. It is about the condition under which a certain cosmic injustice exists. It is only derivatively and defeasibly about what the state should do. Other factors bearing on desirable state policy, including the alleged importance of state neutrality, cannot refute modified luck-egalitarianism. In addition, modified luckegalitarianism is probably more easily workable than the concern about state neutrality would suggest. It is true that branding someone's choice to take a risk culpable requires moral judgment. But that judgment need not rest on a determinate conception of the good. It can rest on other normative judgments. Specifically, notions of culpability and moral wrongness, which are key in modified luck-egalitarianism, are key in theories of just punishment. Since state neutrality does not preclude appeal to such notions in punitive contexts, it should not preclude such appeal in distributive contexts. It is also important to remember that some leading political philosophers doubt that state neutrality is possible and desirable.

\section{g) Circularity}

Another worry raised by the moralized nature of modified luckegalitarianism concerns circularity. The output of egalitarian theory is normative. On pain of circularity, that rules out the use by modified luckegalitarianism of normative input about the culpability of determinate choices to take risks.

I reply that different normative statements can have different contents such that using one to substantiate the other need not be circular. Presumably we agree that it is not circular to use the culpability of an act in order to establish that punishment would be just. Likewise, it is not circular to use the culpability of an act in order to establish that noncompensation of resulting losses would be just.

In sum, modified luck-egalitarianism and its success in explaining our intuitions regarding Hero and Acceptable withstand the objections I have considered.

15 Samuel Scheffler raises the charge of "moralism" against luck-egalitarian theories ("choice, circumstance and the value of equality," Politics, Philosophy \& Economics 4 (2005): pp. 5-28, pp. 14-16); that charge may seem more suitable against modified luckegalitarianism in particular. 


\section{Toward a General Theory of Justice}

The proposed modification of luck-egalitarianism could contribute to a theory of justice itself: a theory of what is common to both distributive justice and punitive justice and makes both into manifestations of justice. Philosophers nowadays rarely offer theories of justice itself. But, assuming that what we call distributive justice and punitive justice manifest different aspects of justice in the same sense of justice, we may posit that there is such a thing as justice in itself, and that it could be interesting to explore.

A plausible theory of justice itself would point out nontrivial affinities between a plausible theory of distributive justice and a plausible theory of punitive justice. It would conclude that these shared features are likely components of justice itself. Consequently, a constraint on a plausible theory of distributive justice is that any such theory must have a nontrivial affinity with a plausible theory of punitive justice; a constraint on a plausible theory of punitive justice is that any such theory must have a nontrivial affinity with one of distributive justice. (For simplicity's sake, I am setting aside the theory of justice at war, which, notably, focuses on innocent suffering.)

Now modified luck-egalitarianism subsumes considerations of moral culpability and moral innocence, which clearly affect justice in punitive contexts, among the ones affecting justice in distributive contexts. This is an additional merit of modified luck-egalitarianism: it meets the constraint on theories of distributive justice. Thus, modified luck-egalitarianism may bring out the similar concerns that underlie justice in all its manifestations. Justice itself disallows innocents to incur disadvantage. If you are not culpable for a choice - because you never freely made that choice, or because the choice is a righteous one - then it would be especially lamentable if you were "penalized" for that choice. Both literal punishment and other "penalties" — relative disadvantages — that you suffer through anything but your own free and wrongful choice detract from cosmic justice. Unequal ${ }^{16}$ innocent suffering diminishes the justice of a world. In that respect, it does not matter whether disadvantage is imposed on you by Nature, by other individuals, or by lawful authorities, as in court-ordered punishment — although that may make a difference in other respects. ${ }^{17}$ Modified luck-egalitarianism would suggest that the core concern of justice itself is innocent disadvantage, and not simply unequal opportunity.

${ }^{16}$ Just punishment is often said to forbid penalizing innocents (and not penalizing them unequally). But in the real world, note that penalizing innocents is always penalizing them more than some other people are being penalized, which may explain why we do not bother mentioning the inequality requirement. See also note 6 above.

${ }^{17}$ For one thing, doing luck-egalitarian injustice is worse than merely allowing Nature or other people to cause it. It is worse to execute an innocent than it is to allow several innocents to be lynched by third parties. Once modified luck-egalitarianism determines when disadvantage accrues to people unjustly, it can be added (on independent grounds) that doing such injustice is worse than allowing such injustice to transpire. 
This may enable modified luck-egalitarianism to clarify thorny issues in punitive justice theory. Compare reckless driving that leaves accident victims injured with similar reckless driving that does not terminate in an accident. Punitive justice tolerates a severer punishment for the former than it does for the latter. Philosophers have long been struggling to explain why. Doesn't severer punishment for unlucky reckless driving ascribe the driver an absurd level of bad moral luck? Explanations based simply on the value of effective deterrence or on the value of showing victims that society empathizes with their suffering assume, again absurdly, that justice readily permits punishing people far more severely than these people deserve simply to promote social goals such as deterring or manifesting empathy. A better explanation would add that, in choosing to drive recklessly, one takes responsibility for the results, including the possibility of severe punishment in the event of an accident. In other words, punitive justice recognizes something like option luck, and accepts something like the luck-egalitarian principle.

However, this statement should be qualified. Compare reckless driving that terminates in an accident with careful driving that terminates in one. Clearly, justice tolerates a far severer punishment for the former than it does for the latter, although both can result from a free choice to drive and thus to risk accident and its potential repercussions. A possible explanation is that the free choice to drive recklessly is morally culpable, unlike the free choice to drive, but to do so carefully. Thus, only the free choice to drive recklessly justifies potential bad results for the driver. In the spirit of modified luck-egalitarianism, the risked disadvantage — light or (in the case of an accident with injured victims) severe punishment cannot do injustice to reckless drivers. Disadvantage arising from the disadvantaged party's culpable choice is consistent with justice - in distributive as well as in punitive contexts.

This may also explain why, while it is generally wrong to punish innocents, failing to punish the guilty when there is no special social interest in punishing them can be acceptable. By culpably choosing to commit crimes, the guilty have legitimated society's imposing on them the disadvantage of being punished. Innocents did not make choices that legitimate punishing them. There is, however, little reason to impose the disadvantage of punishment on the guilty when society stands to gain nothing from doing so. In particular, failure to punish them does not detract from egalitarian justice. The fate of someone whose culpable choice does not disadvantage him is not unjust in egalitarian terms. ${ }^{18}$

${ }^{18}$ The idea that punishing innocents is worse than failure to punish the guilty is associated with H. L. A. Hart, Punishment and Responsibility (Oxford: Oxford UP, 1968). Note that, while failure to punish the guilty is itself permissible, discriminatory failure (punishing only war criminals who are not our allies) is to a certain degree unjust. If one guilty person is punished, it is unjust toward that person that other persons guilty of a similar crime should not be punished. Again, we may explain this in the spirit of modified luckegalitarianism. If I am being punished more than similar war criminals are punished, then my relative disadvantage reflects some factor beyond my control and potential culpability, namely, the punishers' discrimination against me. That I am punishable at all reflects factors that made my choice culpable. 
There is, of course, more to punitive justice than that. The appropriate punishment depends on how wrong the culpable act is. Proportion, therefore, is a further requirement of just punishment. Conduct leading to just punishment must be wrong enough to justify the severity of that specific punishment, and not only free and somewhat wrong, that is, not only culpable. Modified luck-egalitarianism does not cancel the value of proportion to personal desert: some such proportion probably remains desirable. The principle of desert, which cannot successfully substitute modified luck-egalitarianism, complements it nicely. ${ }^{19}$ Nor does modified luckegalitarianism cancel other requirements of punitive justice, such as the special wrongness of doing injustice (see note 17). Like standard luckegalitarianism, modified luck-egalitarianism purports to describe only a component of the relevant normative theory, not the entirety of that theory. I argued here that modified luck-egalitarianism outdoes standard luck-egalitarianism in achieving that moderate aim.

My modified formulation of luck-egalitarianism in terms of culpability, not free choice, copes well, I have argued, not just with the examples of Hero and Acceptable that undermine standard luck-egalitarianism. It copes with several possible objections as well. Modified luckegalitarianism may even promote a theory of justice "itself" that could resolve thorny issues surrounding punitive justice. We have ample reason to embrace modified luck-egalitarianism.

Nir Eyal

Harvard University

nir_eyal@hms.harvard.edu

${ }^{19}$ Compare Arneson, "Luck and Equality," pp. 86-7. 